
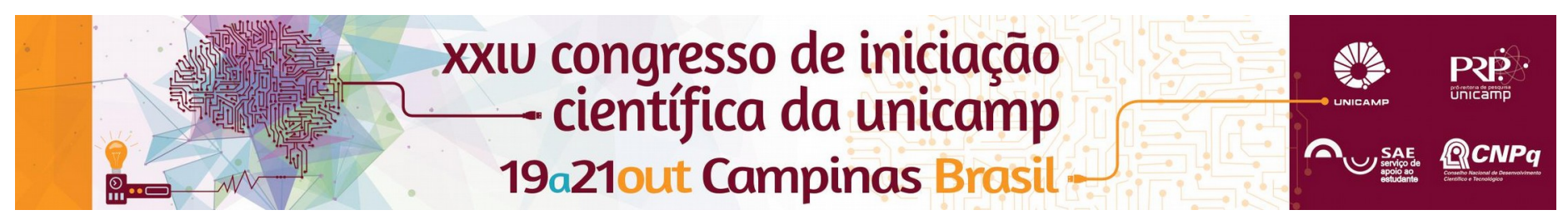

\title{
A representação sindical em setores terceirizados da cidade de Campinas e Região
}

\section{Maísa S. Calazans Silva* , Andreia Galvão}

\begin{abstract}
Resumo
A terceirização é um dos elementos centrais da reestruturação produtiva que vem ocorrendo na economia mundial. Entendemos que a atualidade do tema contrasta com a escassez de material bibliográfico sobre a organização sindical destes trabalhadores. A maior parte dos estudos realizados observa as condições de trabalho nesta nova categoria de trabalhadores sem, contudo, atentar para a organização política destes e a interação com seus sindicatos. Esta pesquisa tem o intuito de mapear a relação dos trabalhadores da base, suas entidades representativas, utilizando para tal os sindicatos SIEMACO Campinas e o SINDEEPRES-SP. A pesquisa sobre as duas organizações tem o intuito de mapear as condições de representação na região, o perfil da direção e da base de filiados, a relação com os sindicatos patronais e as eventuais disputas entre os dois sindicatos pela legitimidade da representação dos trabalhadores terceirizados de Campinas e região.
\end{abstract}

\section{Palavras-chave:}

Sindicalismo, Terceirização, Representação

\section{Introdução}

No mundo do trabalho, a terceirização é um processo com base na flexibilização dos contratos e direitos trabalhistas, inseridas no quadro da reestruturação produtiva em escala mundial. Esse novo movimento tem como característica a superexploração e precarização do trabalho e foi acompanhado do enfraquecimento dos sindicatos como mecanismo de resistência dos trabalhadores. É também acompanhado pela implantação de políticas neoliberais.

De acordo com o relatório elaborado pelo DIEESE em parceria com Márcio Pochmann (2012) aponta que os trabalhadores encontram dificuldades para serem representados pelos sindicatos, para se organizarem e para obter suas reivindicações por melhorias das condições de trabalho e ampliação de direitos (os contratos atípicos deixam essa categoria de trabalhadores descoberta de diversos direitos e benefícios que os funcionários diretos possuem). 0 relatório aponta que apenas pouco menos de 30\% das negociações coletivas analisadas (73 negociações ao todo, ocorridas no período entre 2005 e 2009) previam garantias aos trabalhadores terceirizados. Essa condição cria, de acordo com os pesquisadores, uma segunda categoria de trabalhador, com menos direitos, menos segurança e menos saúde.

Pretendemos abordar as estruturas burocráticas da representação sindical nas categorias precarizadas.

\section{Resultados e Discussão}

Nesta investigação será aplicado o uso de surveys junto aos dirigentes dos dois sindicatos supracitados e com suas respectivas bases, além de revisão bibliográfica sobre os temas da ação sindical, burocracia de Estado e precarização das relações de trabalho.

\section{Conclusão}

A pesquisa está em fase de desenvolvimento, faltando a consolidação dos dados decorrentes dos surveys aplicados para o devido teste das hipóteses levantadas. Entre essas questões a serem verificadas estão a baixa representatividade do sindicato frente à categoria, utilização de mecanismos burocráticos para impedir a organização dos trabalhadores na busca por suas demandas e poucas vitórias na busca por melhores condições de trabalho e remuneração.

\section{Agradecimentos}

Professora Andreia Galvão, DCP - IFCH, amigos e familiares.

AMORIM, Elaine Regina Aguiar. No limite da precarização? Terceirização e trabalho feminino na indústria de confecção. Annablume Editora, 2011.

BRAGA, Ruy. Precariado e sindicalismo no Brasil contemporâneo: um olhar a partir da industria do call center. Revista Crítica de Ciências Sociais, n.103, p.25-52, 2014.

KREIN, José Dari; BIAVASCHI, Magda. "Balanço das tendências da regulação do trabalho no Brasil na primeira década do século XXI." Campinas: Cesit IE/Unicamp, 2013.

KREIN, José Dari; BALTAR, Paulo Eduardo de Andrade. A retomada do desenvolvimento e a regulação do mercado de trabalho no Brasil. Revista CRH, n.68, p.273-292, 2013.

MARCELINO, Paula Regina Pereira. Trabalhadores Terceirizados e Ação Sindical. Editora Appris, 2013.

MARCELINO, Paula R. Pereira; BOITO JR, Armando. Novo operariado, velhos desafios: o sindicalismo dos trabalhadores terceirizados. Revista Estudos de Sociologia, n.31, p.341-362, 2011.

McILROY, John. Os Sindicatos e o Estado. In: Do Corporativismo ao Neoliberalismo: Estado e trabalhadores no Brasil e na Inglaterra. Org. ARAUJO, Ângela Maria Carneiro Boitempo Editorial, 2002.

POCHMANN, Marcio; DIEESE. Terceirização e negociação coletiva: velhos e novos desafios para o movimento sindical brasileiro. Nota técnica, DIEESE, 2012.

TRÓPIA, Patrícia Vieira. Sindicalismo Comerciário: Retaguarda e conservadorismo politico. Caderno AEL, n.12/13, 2000. 